Article

\title{
Leipzig's Inner East as an Arrival Space? Exploring the Trajectory of a Diversifying Neighbourhood
}

\author{
Annegret Haase *, Anika Schmidt, Dieter Rink and Sigrun Kabisch \\ Department of Urban and Environmental Sociology, Helmholtz Centre for Environmental Research, 04318 Leipzig, \\ Germany; E-Mails: annegret.haase@ufz.de (A.H.), anika.schmidt@ufz.de (A.S.), dieter.rink@ufz.de (D.R.), \\ sigrun.kabisch@ufz.de (S.K.) \\ * Corresponding author
}

Submitted: 13 February 2020 | Accepted: 8 May 2020 | Published: 28 July 2020

\begin{abstract}
The article analyses and discusses the development of Leipzig and especially its inner east as an 'urban space of arrival' since 1990. It represents a study about arrival in the post-socialist context that is fairly rare in the international debate so far, since most of the arrival debate builds on western European evidence. Leipzig's inner east was characterised by shrinkage until the end of the 1990s and by new growth, especially after 2010, as the whole city grew. Since the second half of the 1990s the inner east has developed into a migrant area, referred to here as an 'arrival space.' Today, in 2020, it represents the most heterogeneous part of the city in terms of population structure and is one of the most dynamic areas in terms of in- and out-migration. At the same time, it represents an area where large amounts of the population face different types of disadvantage. Set against this context, the article embeds the story of Leipzig's inner east into the arrival debate and investigates the area's development according to the characteristics discussed by the debate. Our results reveal that Leipzig's inner east represents a meaningful example of an arrival space in a specific (post-socialist, shrinkage followed by regrowth) context and that arrival and its spatial allocation strongly depend on factors like population, housing, and real estate market development, as well as policymaking and, significantly, recognition.
\end{abstract}

\section{Keywords}

arrival spaces; Leipzig; migration; neighbourhood; regrowth; shrinkage

Issue

This article is part of the issue "Urban Arrival Spaces: Social Co-Existence in Times of Changing Mobilities and Local Diversity" edited by Yvonne Franz (University of Vienna, Austria) and Heike Hanhörster (ILS-Research Institute for Regional and Urban Development, Germany).

(C) 2020 by the authors; licensee Cogitatio (Lisbon, Portugal). This article is licensed under a Creative Commons Attribution 4.0 International License (CC BY).

\section{Introduction}

Like other cities in the socialist German Democratic Republic (GDR), the city of Leipzig had a population that was highly homogenous in terms of social and national backgrounds. Until 1989, the proportion of migrants was very low due to restrictive immigration rules. This only changed with the peaceful revolution in 1989/90, when the borders were opened and the GDR and the Federal Republic of Germany (FRG) became one state with more liberal immigration rules.
After 1989-1990, the city of Leipzig experienced profound demographic, social, and economic changes: a specific post-socialist transformation. This encompasses population shrinkage and economic decline in the 1990s, stabilisation, moderate growth and reurbanisation in the following decade of the 2000s, and dynamic regrowth and economic recovery since 2010.

While in-migration of migrants and/or people with a migration background (i.e., persons who were born without German citizenship or have at least one parent who was born without German citizenship) did take place over 
the last three decades, it intensified during more recent years and concentrated in particular districts. Leipzig's inner east became one of the areas with a concentration of migrant households. This is all the more astonishing because the economic and social situation in Leipzig at that time was rather unattractive for in-migration, due to deindustrialisation and high rates of unemployment (> 20\%) until the early 2000s. The situation thus majorly differed from western German cities, which are much more prominent in the discourse on immigration and arrival. Embedded in this specific Leipzig context, however, the inner east attracted low-income households, the majority of which were migrant households. Today, the area is well-known and celebrated as a migrant area but is increasingly endangered by rising rents and incipient upgrading.

In this article, we critically reflect on the trajectory of this area as an arrival space since 1990. We analyse causes and impacts of heterogeneity and how they are interrelated with housing market and neighbourhood development. We pursue two research questions:

RQ1: How can we outline the development of Leipzig's inner east by applying the perspective of urban arrival spaces?

RQ2: What can we learn from the example of Leipzig for the general debate on urban arrival spaces?

The article is structured as follows: In Section 2, we introduce and discuss the debate on urban arrival spaces; in Section 3, we describe Leipzig as a case study as well as the materials and methods used; in Section 4, we explain the story and characteristics of Leipzig's inner east as an arrival space, before we discuss our empirical findings in light of the literature in Section 5. Section 6 provides some concluding remarks.

\section{Urban Arrival Spaces: An Emerging Debate}

The scientific debate on urban spaces that are characterised by the arrival of new inhabitants is not new. From a historical perspective, debates about 'urban arrival spaces' go back to the Chicago School and the 'zones of transition.' These zones were used to describe inner-city areas in the USA with a heterogeneous population and high in- and out-flows, as well as community, retail, and labour market structures that support the settlement of new inhabitants at times of dynamic immigration (Park \& Burgess, 1925).

Recently, debates on "arrival spaces," "urban arrival infrastructures" (Meeus, van Heur, \& Arnaut, 2019), and related "localized resources in zones of transition" (Schillebeeckx, Oosterlynck, \& de Decker, 2019) have (re-)emerged and reflected the increased level and visibility of migration in urban spaces as well as daily practices in cities. The book Arrival City by Doug Saunders (2010) played a significant role to push this growing discourse.
The book presents insights from various arrival neighbourhoods in cities on all continents and discusses their potential to facilitate arrival and settling. In Germany, the debate about various dimensions of "arrival" and the discourse of urban arrival spaces was accelerated by the "long summer of migration" in 2015 (Kasparek \& Speer, 2015) and the reception of large numbers of refugees (e.g., Kurtenbach, 2015; Werner et al., 2018).

The scientific debate around urban arrival spaces mostly revolves around heterogeneous populations in specific urban areas. Those areas are inhabited by a high proportion of people with an international biography, have a high level of in- and out-migration, thus a high fluctuation of inhabitants and a relatively high proportion of socially disadvantaged people (e.g., people with a low income and/or state welfare recipients). Furthermore, areas that are referred to as urban arrival spaces are characterised by lower rents compared to other urban areas, as well as the existence of diverse support structures, networks for newcomers such as job opportunities, assistance/social associations (Biehl, 2014; Kurtenbach, 2015; for a summary, see also Hans, Hanhörster, Polívka, \& Beißwenger, 2019), and (street-level) networks and infrastructures for the exchange of goods, services, information, and care (Hall, King, \& Finlay, 2017).

The debates on urban arrival spaces emerged as a 'counterpart' to the established problem-oriented perception of 'parallel societies,' 'disadvantaged' neighbourhoods, and segregated inner-city areas ("ethnic enclave" [Wilson \& Martin, 1982], "immigrant enclave" [Portes \& Manning, 1986]). Such delimiting terms dominated the discussion about urban areas with a high proportion of people with an international biography-even if some of the debates responded positively to the aspect of diversity (see Faist \& Häußermann, 1996; Häußermann \& Siebel, 2001).

The recently established debate stresses the positive and promising aspects of such areas and their potential for socio-economic (upward) mobility, housing consolidation, and the settlement of newcomers. Referring to the notion of "urban zones of transition," Schillebeeckx et al. (2019) support the perspective that a concentration of migrant newcomers in a neighbourhood leads to a "specialisation" in arrival and transition within that neighbourhood. This paradigm shift is also supported by various studies, including one by Rodatz (2012) who discusses the notion of "productive parallel societies" where migration is referred to as a "cultural resource." He observes a shift from a deficit-oriented integration policy towards an urban policy that acknowledges migration and views migrant districts as productive and resourceful sites of diversity. The perspective of arrival spaces or "migrant hubs" (Biehl, 2014) emphasises opportunities for settling, finding housing, a job, and networks for consolidation, and social upward mobility (Meeus et al., 2019). Even if the arrival spaces debate does outline the role of these structures for longer term social and economic participation, the focus lies on 
the first steps after arrival and the first phases of societal integration. Conflicts are understood as a subject of negotiation rather than as a problem; they are seen as a normal part of daily life in heterogeneous environments (Blokland, 2017; Meerow, Newell, \& Stults, 2016).

There is a large and rapidly increasing body of literature around debates on heterogeneous urban environments, diversity, and differences. Such debates focus on how people perceive and cope with diverse environments in their daily life and practices (e.g., Anthias, 2013; Valentine, 2013; Vertovec, 2007). Studies look at the ways in which people interact in these environments and how encounters between different social groups may decrease social distance and prejudices-although the results are quite mixed, depending on whether a more optimistic or a more pessimistic view is taken (see Fincher \& Iveson, 2008; Schillebeeckx et al., 2019; see Bannister \& Kearns, 2013; Nast \& Blokland, 2014; Valentine, 2013, for a rather pessimistic view; see Großmann et al., 2020, for a summary).

Consequently, the arrival spaces perspective focuses on the situation and circumstances of 'arrival' in heterogeneous and dynamically changing neighbourhoods. In this context, 'arrival' can be understood as the settling and improvement of living conditions in terms of social, economic, and political inclusion, for which the arrival neighbourhoods offer supportive conditions. This can have different consequences in the longer term: Either newcomers stay in the neighbourhood and improve their living conditions, or they stay there without enhanced social mobility. Moving to another neighbourhood might be difficult or impossible (e.g., due to housing costs) and such a move could mean either an increase or a decrease in social and economic opportunities. However, we would like to underline that the focus on 'arrival' itself is not without its problems, since it entails the danger of misinterpretation or can imply a blurred perspective, because it separates the arrival of so-called migrants from a much more complex constellation of urban in- and outmigration. This runs the risk of overinterpreting the presence of a migration biography and undermining an intersectional perspective of the social and economic living conditions in such areas. Critical studies speak of a "migrantisation" of social contexts (e.g., Dahinden, 2016) or look at stigmatisation by categorisation (for example, when a migration biography is viewed as a 'natural' and core feature of a person). Still, the majority of neighbourhoods described as arrival spaces show high proportions of low-income households and people who depend on state welfare and, among those groups, a high proportion of people with a migration background. Thus, in our study, we focus on the arrival of people with a migration background who face an above-average number of barriers, e.g., due to language issues, different kinds of residence permits, as well as structural and practical problems regarding access to jobs and housing. These population groups are additionally disadvantaged even if the level of disadvantage and exposure to discrimination may vary considerably. A limited, positive description of 'arrival' as an asset or potential of the related spaces at least opens a door to neoliberal thinking and the deliberate disregard of their multiple disadvantages.

Arrival spaces may emerge and develop at different places across a city; their development depends on the overall housing market conditions and might change over time (Dunkl, Moldovan, \& Leibert, 2019). We can identify different constellations or pathways of arrival spaces such as: a) "established, long-term" arrival spaces; b) areas where the arrival characteristics are being endangered by upgrading, displacement, and residential change; or c) areas where people move to due to a lack of alternatives (Haase \& Schmidt, 2019). Arrival spaces thus may shift in terms of place, but they may also shift in meaning for the people living there. What is more, arrival spaces do not necessarily end at the neighbourhood border: they may include the city as a whole and even exceed the city limits (Hans et al., 2019).

The current debate on arrival spaces has discussed the causes and effects of housing market development and gentrification in so-called ethnic/migrant neighbourhoods and those shaped by migrant-related business zones (Hwang, 2015; Murdie \& Teixeira, 2010; van Gent \& Musterd, 2016), especially in the context of tourism and consumption (Fainstein \& Powers, 2007; Shaw, Bagwell, \& Karmowska, 2004) or the stresses of increased social diversity (Budnik et al., 2016). However, the links between neighbourhood upgrading and displacement have not been intensely researched yet. Some studies refer to the challenges of rising attractiveness and upgrading, particularly for inner-city arrival spaces in cities with contested housing markets, such as Leipzig's inner east. Generally, there is a need for more research at the intersection between arrival and gentrification, from the perspective of both strands of the debate. Having provided the context of this debate, we will now look at Leipzig as an arrival space with a focus on the inner east.

\section{Materials and Methods}

\subsection{Leipzig as a Case Study}

Before characterising the migrant situation in Leipzig, it is necessary to mention some key points of its recent history that occurred during the transformation following German reunification. The specifics of the postsocialist transformation in Leipzig are embedded in the integration of the GDR into the FRG. West Germany served as a blueprint for the transformation, which followed the paradigm of 'catch-up modernisation.' It was expected that the eastern cities 'return' to the position and role within the urban hierarchy that they had held before 1945. Back then, Leipzig had been the fifth largest city in Germany. Laws and institutions were completely adapted to FRG rules. From one moment to the next, eastern Germany had become part of the capitalist world 
economy, which was a shock to the system. Leipzig experienced a rapid privatisation of companies in the early 1990s. Most of the companies were closed down, which brought about widespread deindustrialisation ( $>80 \%$ ) and mass unemployment ( $>20 \%$ ) in Leipzig. In the real estate and housing sector, ownership issues and restitution remained a challenge until end of 1990s. As a result, more than $70 \%$ of the pre-1918 housing stock in Leipzig is now owned by west German capital investors, real estate funds, and investment companies.

The East German city of Leipzig has quite a specific migration history. During the GDR time and until the political change in $1989 / 90$, the city had a very low number of migrants - they made up around $2 \%$ of the population. Nevertheless, with about 12,000 migrants, Leipzig had the second largest community of migrants in the GDR (after East Berlin) and was considered one of the most cosmopolitan cities in the country. These migrants were mainly international students and contract workers, mostly from other socialist countries, who lived in Leipzig for a restricted period of time. After the German reunification, most contract workers and students had to leave the city. Only a small number were allowed to stay. Shortly after reunification, so-called 'late repatriates' from the former Soviet Union (people of German origin) and people from western Germany with international biographies moved to Leipzig. At that time, Leipzig's housing market was still rather contested and the existing vacant apartments were uninhabitable due to disinvestment. The inner east was one of the neighbourhoods where migrants were able to find affordable apartments at that time. From the mid-1990s onwards, Leipzig's first arrival space emerged in this area. For this article, we thus focus on the city's inner east and especially the urban districts of Neustadt-Neuschönefeld (NN) and Volkmarsdorf (V) and the central retail and transport axis Eisenbahnstrasse (see Figure 1) that runs through both neighbourhoods.

At present, Leipzig has some 85,000 people with a migration background, which is $14.2 \%$ of the total popula- tion. It is on the way to becoming the eastern German city with the largest amount of inhabitants with a migration background (with the exception of Berlin). Currently, within the city one can observe the emergence of a number of neighbourhoods that can be characterised as arrival spaces (Dunkl et al., 2019).

\subsection{Empirical Evidence and Methods}

This article is based on long-term area observation and research results from different projects that deal with socio-spatial differentiation, poverty, segregation, innercity residential change, reurbanisation, the governance of shrinkage, and ways of coping with rising population diversity. For the 1990s, these projects include, for example, the Social Atlas of Leipzig that examined the segregation of the population and highlighted the multiple disadvantages of Leipzig's inner east in the early and mid1990s (Kabisch, Kindler, \& Rink, 1997), a scientific report financed by the municipality on living circumstances that shows the accumulation of inequalities in Leipzig's inner east (Stadt Leipzig, 1999), as well as another project that identified the concentration of poverty in this area (Richter, 2000). In the 2000s, Leipzig's inner east was studied in terms of inner-city reurbanisation after decline; international migrants were identified as one of the groups driving the renewal (Haase, Herfert, Kabisch, \& Steinführer, 2012). The EU project Shrink Smart then dealt with the urban restructuring in Leipzig's inner east at the end of the 2000s/beginning of the 2010s, and detailed the partial upgrading through greening and restructuring measures (Rink, Bernt, Großmann, \& Haase, 2014). The increasing social heterogeneity in the area and issues of perception and coping with diversity were studied in another EU project titled Divercities from 2013-2017 (Budnik et al., 2016, Haase et al., 2019). Those studies are based on different data sets obtained through various qualitative and quantitative methods. The advantage of this long-term perspective is that despite the changing foci of the aforementioned projects,
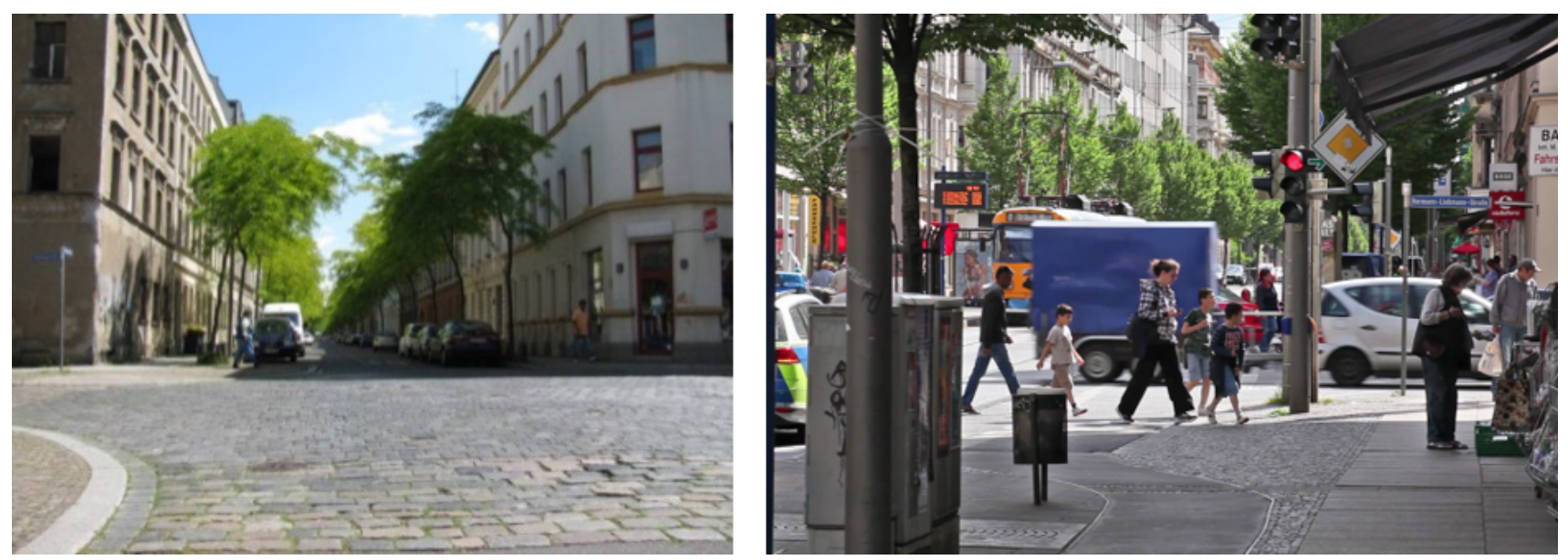

Figure 1. The old built-up area of Leipzig's inner east (left) and the central axis Eisenbahnstrasse (right). Source: A. Haase and EU project Divercities. 
we are still able to trace the development of this area with our own empirical material and can compare it with the development of the entire city.

For empirical illustration, we make use of local statistics related to the arrival space criteria (i.e., data on population and household development, socio-economic and income data, the housing market situation and housing conditions, funding schemes), as well as empirical evidence gathered from the above-mentioned projects (e.g., expert and household interviews, surveys, practice formats such as participatory events in green spaces, workshops, in-situ observations and mapping, as well as the assessment of municipal policy and planning documents). When referring to those results in the empirical part of our article, we will indicate the type of research and where the original results were published.

\section{Story of Leipzig's Inner East as an Arrival Space}

\subsection{Tracing the Development of the Area}

Leipzig's inner east is a former working-class area close to the city centre that emerged adjacent to the railway tracks in the second half of the 19th century. It was a densely built area characterised by the pre-1918 housing stock. Later, after some parts of the railway tracks were removed, the Eisenbahnstrasse (which literally translates as 'railway street') formed a central transport and retail axis. Already at this time, the area was a kind of transition zone, with a lot of in- and out-migration and many working-class households. It was called 'the red east' due to the high numbers of residents who were members or voters of the workers' left-wing parties. Some parts of the area had a bad reputation due to crime.

During the GDR, the area suffered from neglect, longterm disinvestment, decay, and both residential and commercial vacancies, which led to a massive rent gap. After 1990 the area experienced enormous population shrinkage, but at the same time the first signs of an emerging arrival space appeared. In the 1990s, nearly two thirds of the pre-war housing stock had been refurbished, leading to a consolidation of the residential function. This specific combination of population decline and structural upgrading prevented the closure of the rent gap and there was a lack of solvent demand for housing. In the 2000s, Leipzig's east experienced reurbanisation that was particularly driven by migrants. Since 2010, the area has faced dynamic population growth and upgrading. In the course of this process, the character of the area as an arrival space has become increasingly contested (Haase \& Rink, 2015), the growth of the 2010s was mainly driven by migrants. Nowadays, Leipzig's inner east represents one of the most dynamically growing neighbourhoods in a growing city. The area can be seen as an established urban arrival area facing very heterogeneous in-migration in relation to age, income status, household status, and nationality.
Table 1 provides a more detailed overview of the phases of development.

\subsection{Socio-Demographic and Socio-Economic Structures}

The municipal statistics provide evidence that the NN and $V$ districts, which encompass the arrival area, have an above-average proportion of people with a migration background and people with a non-German nationality compared with Leipzig as a whole (see Table 2). Among the inhabitants with a migration background and without German citizenship, we find a large number of nationalities; the largest groups are people from Russia, Iraq, Syria, Afghanistan, Vietnam, and Romania, which indicates the diversity of countries. In contrast to many western German cities, there are many first-generation migrants and a considerable share of late repatriates from the former Soviet Union. Since 2000, NN and V are the only districts (apart from the city centre) with a constant share of migrant population that is more than double the city average (Schmidt, 2016, p. 40). The average age of the population is lower than in other districts, especially due to the migrant population and the comparably high proportion of children among migrant households (Martin, 2018, p. 14). In both districts, the youth rate is higher and the rate of elderly people is considerably lower compared to the city average (see Table 2).

As for the migration balance, after the out-migration that occurred until the late 1990s, both districts saw a constant positive migration balance from 2000 onwards. After 2010, they were among the districts in Leipzig's inner city with the highest yearly growth rates-this was also due to the fact that, back then, they still had higher vacancy rates and could absorb more people. At the time of the 2011 census, NN had a vacancy rate of $25.3 \%$ and $V$ of $34.7 \%$, which are extremely high values (for comparison, the city average was $12.1 \%$; Statistisches Landesamt Sachsen, 2014, p. 16). The vacancy rate across the city as a whole has meanwhile fallen to approximately $4 \%$ (2018), while in NN it is probably twice as high and in $V$ three times as high (our estimations are based on information from local housing market experts as well as a mapping of vacancies in the area in early 2020). This is shown by a mapping of a part of Leipzig's inner east in March 2020 that revealed a vacancy rate of $17.3 \%$ in non-renovated, pre-war housing stock.

Values for in- and out-migration are more than double the city average (see Table 2) and the same holds true for total migration compared to number of inhabitants. Subsequently, we observe a high fluctuation of inhabitants in Leipzig's inner east as is typical for arrival spaces. High fluctuation does not just refer to migrant households but to other households as well.

Both areas also show an above-average proportion of low-income households and welfare recipients. In NN, these figures are double the city average and they are even triple in V (2017, see Table 2). Looking at income apart from welfare, we see a noticeable difference be- 
Table 1. Development of Leipzig's inner east since 1990.

\begin{tabular}{ll}
\hline Phase & Description \\
\hline $\begin{array}{l}\text { Decay, out-migration, } \\
\text { and renewal }\end{array}$ & $\begin{array}{l}\text { The area experienced large-scale population losses that had already started before the peaceful } \\
\text { revolution. It suffered from the decay of old built-up stock due to long-term disinvestment prior } \\
\text { to } 1990 . \text { A considerable proportion of the apartments was vacant and uninhabitable (1995 }\end{array}$ \\
First half of & $\begin{array}{l}\text { vacancy rate in NN: } 28.8 \%, \text { in V: } 15.5 \% \text {; Stadt Leipzig, 1995). The demolition of old building } \\
\text { the 1990s }\end{array}$ \\
& $\begin{array}{l}\text { stock and its replacement with GDR-style prefabricated concrete buildings had stopped. } \\
\text { The renovation of building stock started (Doehler \& Rink, 1996). }\end{array}$
\end{tabular}

Emergence of a space of arrival

Second half of the 1990s

Consolidation of neighbourhood and arrival space

2000s

Dynamic growth and insipient upgrading; arrival space endangered?

2010s
Population losses continued while more and more old buildings were renovated. Vacancies also emerged in renovated housing. By the end of the 1990s, the population losses slowed down and new in-migration started due to the availability of renovated housing in central locations and low housing costs caused by significant oversupply (Großmann, Arndt, Haase, Rink, \& Steinführer, 2015). Among the new in-migrants, there were particularly increasing numbers of migrant households. Migrant-owned retail emerged while rates of commercial vacancies remained high.

The area experienced a period of moderate inner-city reurbanisation, mainly driven by young(er) one-person households, cohabiting households, shared apartments, among them increasingly migrants, students, and low-income families. The percentage of migrants reached figures considerably exceeding the city average (Haase et al., 2012). A smaller part of the dilapidated housing was demolished and further renovation took place, forming the basis for further in-migration. Additionally, the area saw the restructuring and greening of streets and the enlargement of Rabet Park through public funds. Support infrastructure for the inhabitants was created through publicly funded programmes, partly addressing migrants' needs. The support infrastructure mainly helped to prevent the further decline of the area; it also backed and fostered civil society engagement.

Set against the context of dynamic regrowth in Leipzig as a whole, the city's inner east neighbourhoods experienced in this decade new growth rates of $20-30 \%$. In-migration included students, early-stage professionals, artists, lower-income families, and single parents; people with a migration background were increasingly well represented among in-migrants.

The majority of building stock is renovated, there are also some examples of upmarket renovation. Vacancies are vanishing, housing costs are increasing, and a debate about gentrification, displacement, and the protection of residents has started (Haase et al., 2019; Haase \& Rink, 2015). Despite cuts in funding, support infrastructure continues to exist; migrant self-organisation has become more important. tween the districts: In NN, $70 \%$ of all household income stems from employment, in V it's only $52 \%$; in $\mathrm{V}$, both individual and household income are considerably below the city's average (Stadt Leipzig \& Amt für Statistik und Wahlen, 2018, pp. 75, 79). In both areas, there is a low percentage of employed people, which is due to a higher percentage of welfare recipients and unemployed people (this applies more to $\mathrm{V}$ than to $\mathrm{NN}$; see Table 2). In addition, the area also became attractive for student households (shared apartments), which are part of the low(er) income population. The share of students is higher in these neighbourhoods compared to the city average (e.g., Haase et al., 2012).

These features coincide with the rent level, which is still low in both areas meaning that affordable housing is available. But, here too, we see a difference between $\mathrm{V}$ and NN (Stadt Leipzig, 2018, pp. 76, 80): in V, rents are today (in April of 2020) lower than in NN. This fact is in line with the lower employment rate and lower income in V. Over the past few years, NN saw a certain degree of 'consolidation' in terms of its residents' socio-economic situation. Still, it can be seen as an arrival space in relation to population composition, proportion of migrants, and fluctuation, although less so with regard to income and housing.

The arrival of migrants in the second half of the 1990s stopped further decline, decreased vacancies in the housing stock, and led to the re-use of retail space, thus keeping the area liveable and vibrant. Support structures and funding spent on newcomers helped to make the area more attractive (establishment of two parks, renovation of streetscapes, planting of street trees, etc.). Moreover, these structures formed an environment where newcomers could get advice and help to 
Table 2. Selected socio-demographic and socio-economic data for Leipzig and the districts NN and V for the period 2000-2017.

\begin{tabular}{|c|c|c|c|c|c|c|c|c|c|c|c|c|}
\hline & & 2001 & & & 2005 & & & 2011 & & & 2017 & \\
\hline & Leipzig & NN & V & Leipzig & NN & V & Leipzig & NN & V & Leipzig & NN & V \\
\hline Inhabitants & 519420 & 9272 & 8069 & 528156 & 9969 & 8315 & 517838 & 9408 & 7952 & 590337 & 12687 & 12676 \\
\hline $\begin{array}{l}\text { Population } \\
\text { with migration } \\
\text { background (\%) }\end{array}$ & n.a. & n.a. & n.a. & n.a. & n.a. & n.a. & 8.6 & 29.4 & 28.1 & 14.1 & 36.2 & 42.1 \\
\hline $\begin{array}{l}\text { of these: } \\
\text { Foreigners (\%) }\end{array}$ & 4.7 & 10.8 & 10.0 & 5.1 & 16.4 & 14.8 & 5.2 & 20.4 & 19.0 & 9.5 & 25.7 & 32.7 \\
\hline $\begin{array}{l}\text { Welfare } \\
\text { recipients * (\%) }\end{array}$ & 5.5 & 13.3 & 15.2 & 15.2 & 31.3 & 37.3 & 14.3 & 32.1 & 31.9 & 10.8 & 22.4 & 31.3 \\
\hline $\begin{array}{l}\text { Unemployment } \\
(\%)\end{array}$ & 12.9 & 18.2 & 20.1 & 14.0 & 22.6 & 25.3 & 8.8 & 14.6 & 19.5 & 5.4 & 7.8 & 10.8 \\
\hline Employment (\%) & 48.7 & 45.3 & 43.1 & 43.7 & 33.8 & 31.6 & 52.8 & 38.5 & 35.0 & 58.2 & 44.5 & 37.9 \\
\hline Students (\%) & n.a. & n.a. & n.a. & n.a. & n.a. & n.a. & 6.0 & 15.0 & 10.0 & 11.0 & 19.0 & 22.0 \\
\hline Average age ** & +42.7 & -11.8 & -10.3 & +43.1 & -6.0 & -5.2 & +43.8 & -6.5 & -4.3 & +42.4 & -7.6 & -7.9 \\
\hline Youth rate $* *$ & 14.4 & 8.0 & 17.5 & 13.3 & 2.0 & 3.4 & 18.2 & 0.1 & 0.9 & 20.6 & 4.3 & 1.8 \\
\hline $\begin{array}{l}\text { Migration } \\
\text { balance per } \\
1000 \text { inhabitants }\end{array}$ & +5.8 & +17.4 & -36.1 & +5.4 & +16.6 & -16.4 & +18.9 & +30.2 & +42.5 & +17.4 & +28.4 & +89.8 \\
\hline $\begin{array}{l}\text { Rent load quota } \\
\text { (\% of income) }\end{array}$ & n.a. & n.a. & n.a. & n.a. & n.a. & n.a. & 34.0 & 37.0 & 36.0 & 30.0 & 30.0 & 38.0 \\
\hline
\end{tabular}

Notes: * until 2004 recipients of Sozialhilfe (welfare benefits) and, from 2005 onwards, recipients of benefits according to SozialGesetzBuchII (Social Act II); ${ }^{* *}$ V and NN difference to city average. Source: Based on municipal data from Stadt Leipzig \& Amt für Statistik und Wahlen $(2002,2006,2012,2018)$.

cope with the demands of daily life. Importantly, the support structures helped to set up the basic conditions for keeping the area attractive, so that it could become a new hub for arrival.

As a consequence of rising rents in Leipzig's inner east, the neighbouring districts face international in-migration where people just move in, but still use the support infrastructure in the area around Eisenbahnstrasse. Since 2015, 'new' spaces of arrival have emerged in other districts of Leipzig, in particular during the massive in-migration streams of 2015/16. The large housing estates at the eastern and western fringes of the city are among the last districts that offer low-cost housing. In this context, we are tempted to speak of 'forced' arrival spaces, as these areas are among the only ones still affordable for low-income households. However, these areas currently do not offer the kind of opportunity and support structures that we find in Leipzig's inner east. Therefore, many migrants travel from their residential locations to the inner east to go shopping and foster contacts.

By and large, one can summarise that arrival in Leipzig's inner east became increasingly 'migrationbased' over the last two decades; migrants arriving here are very heterogeneous with respect to national, professional, and educational background. Migration-based arrival intertwines with non-migrants coming to the area.

\subsection{Policy, Planning, Networks, and Recognition}

As mentioned in Table 1, the area has developed dynamically since 1990. At the beginning of 1990s, three largescale redevelopment areas were established in Leipzig's inner east and renovations were supported by federal urban renewal programmes. At the end of the 1990s, due to the concentration of poor people with and without a migration background, a high crime rate, and the emergence of a drug scene, Leipzig's inner east was declared a 'social hotspot.' Basing on that in the early 2000s, a federal programme to support social cohesion and reduce disadvantage was implemented. The new growth after 2010 made all those developments largely obsolete. Since then, private capital has once again been invested in the renewal of residential buildings and new housing construction. This has caused an increase in rent and property prices. The city council is seeking to define protected areas or milieu conservation areas for Leipzig's inner east (a milieu conservation area is 
based on an instrument called Erhaltungssatzung [maintenance/preservation statute] which is a juridical instrument designed to protect/preserve the built stock/fabric of an area and the composition of its residential population). The aim is to prevent expensive renewal or modernisation of the residential buildings and the subsequent displacement of poorer households including migrant households.

Since 2000, a network of support infrastructure for low-income and other disadvantaged households has been developed around Eisenbahnstrasse, subsidised by funds from the federal government, the state government, and the EU. Parts of this infrastructure specifically address the needs of migrants, e.g., services that help them navigate the bureaucracy, fill out forms, search for a job, etc. Recently, migrant self-organisation has become more important, as has the role of migrants as shop owners and house owners. A study on local businesses clearly indicated how local retail has adapted to clients with a migration background (Kullmann, Großmann, Haase, Haid, \& Budnik, 2018).

In daily life, the heterogeneity of the population in the neighbourhood is largely accepted and people have, in a superficial way, become familiar with it. However, as an interview study revealed in the early 2010s, there is much distance and othering between people, as well as avoidance when it comes to speaking about conflicts (Haase et al., 2019). In recent years, local stakeholders reported a growing level of racism and discrimination, especially after 2015.

In order to fight (drug and other) crime, Eisenbahnstrasse was declared a 'weapon ban zone' in late 2018-one of very few such zones in all of Germany. This status permits police to conduct random checks and there is much debate about whether migrants are checked more often than other people. The local discourse on the area is highly controversial: for instance, Wiest and Kirndörfer (2019) uncover paradoxical negotiations and discursive logics as well as othering processes within local media debates and urban development policies related to the issue of migration and the area around Eisenbahnstrasse. They identify a discursive construction of the "productive deviance" of migrants, when analysing seemingly positive media notions of migrant entrepreneurs and businesses in Leipzig's inner east (Wiest \& Kirndörfer, 2019, p. 12). At the same time, they find a discursive construction of the "migrant criminal," framed as an unproductive deviant within media reports, especially around Eisenbahnstrasse in the years 2014-2015. The overall municipal discourse of the 'city of diversity' remains diffuse and largely anonymous. At the same time, civic society in Leipzig's inner east has started to make the area's heterogeneity and arrival status the subject for debate and celebration; for instance, in 2018, a festival and series of events were organised using the motto "harbour of the city" (Pöge-Haus e.V., 2018).

\section{Discussion}

\subsection{How Can We Outline the Development of Leipzig's} Inner East from the Perspective of Urban Arrival Spaces?

When we look at the development of Leipzig's inner east as an urban space of arrival, we can confirm that the area displays most of the characteristics that are described as typical for such areas in the literature, e.g., in studies by Biehl (2014), Kurtenbach (2015), Hall et al. (2017), and Hans et al. (2019). The area has a high proportion of people with a migration background and households with low income, including those receiving unemployment and other welfare benefits. Fluctuation is considerably higher than the city average. Thus, we can summarise:

a) The area still offers affordable housing for households that depend on low rents, although the amount of affordable housing is decreasing. There is a broad range of support infrastructure including some that specifically addresses the needs of migrants. Migrant self-organisation and migrantbased retail have become important. Apart from the arrival of migrants, which is the dominant form of in-migration, Leipzig's inner east also experiences in-migration by non-migrant households. These vary in terms of type, income, and lifestyle. By and large, 'arrival' has become an important feature of the area and, although it was long ignored, this fact has now been acknowledged by policymakers and local civic society. But still, policymakers do not treat arrival as an important comprehensive issue, perhaps with the exception of the management of refugee arrivals in 2015/16 (Werner et al., 2018). Nowadays, the city tries to protect the area's low-income population from becoming displaced: The area was given a protected status designed to maintain the affordability of its housing. Consequently, it is necessary to emphasise the central role of the housing market and the availability of affordable housing for arrivalaffordable housing is possibly the most important precondition for settling. Thus, the close intersection between arrival and affordability or arrival and precariousness becomes all the more obvious. This has been acknowledged by recent research on Leipzig's inner east, but also on arrival spaces in other cities (Großmann et al., 2020).

b) Internationality has also become more and more normal in terms of daily life and practices. However, since 2015, the level of racism and discrimination against migrants has increased as well, ranging from institutional discrimination, e.g., by landlords or authorities, to verbal and physical attacks. As such, arrival and 'migration' have also become synonyms for conflicts and crime in public discourse. Here our findings are in line with 
Wiest and Kirndörfer (2019), who describe local discourse on the inner east as polarised and contradictory. On the one hand, the city labels itself as cosmopolitan and welcoming. On the other hand, a 'weapon ban zone' was established to counteract crime in Leipzig's inner east in 2018. Criminality is especially assigned to groups of (perceived) migrants and police practices surrounding the enforcement of the zone prompted debates about racial profiling, which opened up questions about how city officials and society perceive and cope with internationalisation. Furthermore, current municipal actions are marked by contradictions and a lack of consistency (see Bernt, 2019).

c) We can identify facts and processes which demonstrate what Schillebeeckx et al. (2019) call the "specialisation" of the arrival area. But we can also see that the 'arrival character' does not remain unchanged over time, an argument that has not yet been greatly debated. The probability of a neighbourhood functioning as an urban space of arrival depends on many factors. Add to this the fact that opportunity structures might decrease or even vanish in the future. Such processes relate to the increased impact of upgrading that endangers households with limited income or which depend on affordable rent. On the one hand, the recent development and increased in-migration made the area more attractive for a large range of people; on the other hand, there are many different and also opposing interests (such as those of housing market actors, the municipality, organised civic society, and groups of residents) regarding how the area should develop in the future and what it should ultimately become. As a consequence, further displacement of low-income households might take place. Thus, Leipzig's arrival spaces might 'move' in the next years and 'evolve' in other areas. This once again highlights the central importance of housing market developments for the existence and decline/emergence of arrival spaces.

\subsection{What Can We Learn from the Example of Leipzig for the General Debate on Urban Arrival Spaces?}

In the following, we summarise some issues that show how our case study contributes to the general debate on arrival spaces:

a) Context of transformation, shrinkage, and regrowth. Applying the arrival perspective to Leipzig's inner east shows how closely intertwined it is with the specifics of the district and its history of shrinkage and regrowth. While the establishment of an arrival space was made possible by the peaceful revolution and the legal situation following German reunification, it was also decisively facilitated by the shrinkage context (vacancies, low housing costs, proximity to city centre). This context even outweighed the area's poor employment prospects. In retrospect, migrants who moved into vacant apartments and opened their businesses in vacant shops during the second half of the 1990s and the early 2000s can be regarded as the pioneers of reurbanisation in Leipzig's inner east. In the context of regrowth that is still ongoing at the time of writing (April of 2020), the new growth that began in 2010 endangers the arrival characteristics as it is leading to increasing housing costs, displacement, and higher barriers for low-income households that wish to access the area. Thus, the hallmarks of incipient gentrification can be observed. The area's vacancies are vanishing, its function as an arrival space is endangered, and new arrivals are increasingly forced to move to areas on the fringes of the city. Housing market developments and housing availability-or rather, a lack of affordable housing-represents one of the most decisive factors governing the existence of arrival spaces, especially in cities that are characterised by contradictory dynamics like shrinkage and new growth in a comparably short time.

b) Arrival as a constellation of multiple favourable factors. The case of Leipzig's inner east shows that arrival can be described as a constellation where a number of favourable factors and enabling conditions come together. These constellations make it easier for newcomers to settle in a certain urban space, but might be dynamically changing (Biehl, 2014 , p. 16). Arrival spaces may shift across the urban territory as we have seen in Leipzig in the second half of 2010s. The spatial allocation and duration of arrival constellations thus depends on many factors such as population development, housing and real estate market development, and the city's economic performance, but also on local policymaking, decision-making, and informal practices (Hall et al., 2017; Meeus et al., 2019; Schillebeeckx et al., 2019).

c) Arrival between acknowledgement and challenge. Arrival has been increasingly acknowledged as a central characteristic of Leipzig's inner east by policymakers and city planners, but also by people, entrepreneurs, and stakeholders who live and work in the area. The area is addressed as an arrival space in public and policy discourse, and the protection of the current inhabitants has become a priority of the city's strategic policymaking, not despising existing problems. However, arrival is being perceived and treated as an issue that represents both a promise and a challenge; the discourse and policymaking are full of contradictions and paradoxes (Wiest \& Kirndörfer, 2019). For a long time 
there has been a lack of acknowledgement that arrival spaces are spaces where low-income households concentrate and that those areas need protection when housing markets become more contested (Haase et al., 2019). Leipzig's case clearly shows that arrival has to be looked at across different levels, from individual neighbourhoods to the entire city (see also Bernt, 2019, p. 65; Werner et al., 2018, p. 122).

d) The importance of bringing arrival into other debates (racism, othering, and discrimination). The Leipzig example demonstrates that it is necessary to combine the perspective of arrival spaces with other perspectives on neighbourhood development and ways of dealing with a multicultural and diversifying urban society. The arrival approach is sensitive to the specific situation of migrants and the many additional barriers they face when settling in a place. Approaches such as intersectionality could help to provide a more complex view on these multiple disadvantages (Großmann et al., 2020). Furthermore, the arrival debate should not undermine the prevailing problems of racism, othering, and discrimination by 'reinterpreting' arrival as a story of challenges that may transform into opportunities. Social conflict theory has always suggested that social conflicts are triggers for change, and explicitly dealing with these conflicts can help to overcome a dichotomist view of 'positive' and 'negative' development. If nothing else, we see an overlap between the arrival debate and the gentrification debate.

e) Overlap between arrival, gentrification, and displacement. The Leipzig case points to some crossover between the debate on arrival spaces and gentrification that have so far been rarely addressed. As we briefly outlined in Section 2, the two debates do not communicate much with each other yet, except for some studies that address those links more or less explicitly. The majority of studies on gentrification do not specifically look at the arrival context, and studies on arrival spaces only occasionally refer to the danger of upgrading and displacement. Due to the housing supply surplus, displacement was not a relevant issue in Leipzig's inner east for a long time. The situation changed when Leipzig started to face dynamic population growth after 2010. To date cases of direct displacement are still rare in Leipzig's inner east, but there is increasing displacement pressure that specifically threatens low-income households, many of which are migrant households. These developments can also be observed in the arrival spaces of other German and European cities.

\section{Conclusion}

Our study revealed that Leipzig's inner east can be defined as an arrival space but with certain specific attributes. Firstly, it is a case of arrival in a post-socialist city that has seen fundamental transformation since 1990. Secondly, arrival in Leipzig and especially the inner east has been strongly impacted and shaped by the overall conditions of extreme shrinkage and, after a short interim of stabilisation, dynamic new growth. The public, the city, and policymakers all recognise that the arrival function is a central characteristic of Leipzig's inner east, which shows a certain degree of normalisation, but this perspective remains ambivalent and contradictory. Since the late 2010s, upgrading, displacement pressure, and increasing housing costs have endangered the area's arrival character, i.e., the many low-income households living there. At the same time, new spaces of arrival are emerging at the fringes of the city. If nothing else, the topic of arrival challenges the way Leipzig's urban society understands itself, as well as broader issues of inclusion, recognition, and citizenship. Thus, the character of a neighbourhood as an urban arrival space has to be addressed as an issue that operates across policy levels and which is dependent on a constellation of favourable conditions that may be short-lived or long-lasting. The case study also showed that there is great potential for crossfertilisation between the arrival spaces debate and other debates about diversifying urban societies and neighbourhood change. Such exchange would help to provide a comprehensive picture and meaningful assessments.

\section{Acknowledgments}

The authors were able to do this research within the framework of the research project "KoopLabParticipation though Open Space Development," financed by BMBF, 2018-2020 (01UR1706C). They wish to thank Anthea Wagner for the support with the vacancy mapping carried out in 2020.

\section{Conflict of Interests}

The authors declare no conflict of interests.

\section{References}

Anthias, F. (2013). Moving beyond the Janus face of integration and diversity discourses: Towards an intersectional framing. The Sociological Review, 61(2), 323-343. https://doi.org/10.1111/1467-954X. 12001

Bannister, J., \& Kearns, A. (2013). The function and foundations of urban tolerance: Encountering and engaging with difference in the city. Urban Studies, 50(13), 2700-2717. https://doi.org/10.1177/ 0042098013477705 
Bernt, M. (2019). Migration and strategic urban planning: The case of Leipzig. disP: The Planning Review, 55(3), 56-66. https://doi.org/10.1080/ 02513625.2019 .1671002

Biehl, K. S. (2014). Exploring migration, diversification and urban transformation in contemporary Istanbul: The case of Kumkapı (MPI MMG Working Paper 14-11). Göttingen: MPI MMG.

Blokland, T. (2017). Community as urban practice. Oxford: Polity Press.

Budnik, M., Grossmann, K., Haase, A., Haid, C., Hedke, C., Kullmann, K., \& Wolff, M. (2016). DIVERCITIES: Living with urban diversity-The case of Leipzig, Germany. Utrecht: Faculty of Geosciences, Utrecht University. Retrieved from https://www.urbandivercities.eu/ wp-content/uploads/2017/02/Divercities-City-BookLeipzig.pdf

Dahinden, J. (2016). A plea for the 'de-migranticization' of research on migration and integration. Ethnic and Racial Studies, 39(13), 2207-2225. https://doi.org/ 10.1080/01419870.2015.1124129

Doehler, M., \& Rink, D. (1996). Stadtentwicklung in Leipzig: Zwischen Verfall und Deindustrialisierung, Sanierung und tertiären Großprojekten [Urban development in Leipzig: Between decay and deindustrialisation, renovation and tertiary large-scale projects]. In H. Häußermann \& R. Neef (Eds.), Stadtentwicklung in Ostdeutschland: Soziale und räumliche Tendenzen [Urban development in Eastern Germany: Social and spacial trends] (pp. 263-286). Opladen: Westdeutscher Verlag.

Dunkl, A., Moldovan, A., \& Leibert, T. (2019). Innerstädtische Umzugsmuster ausländischer Staatsangehöriger in Leipzig: Ankunftsquartiere in Ostdeutschland? [Patterns of foreigners' inner-city house-moving in Leipzig: Arrival neighborhoods in Eastern Germany?]. Stadtforschung und Statistik: Zeitschrift des Verbandes Deutscher Städtestatistiker, 32(2), 60-68. Retrieved from https://nbnresolving.org/urn:nbn:de:0168-ssoar-64116-4

Fainstein, S. S., \& Powers, J. C. (2007). Tourism and New York's ethnic diversity: An underutilized resource? In J. Rath (Ed.), Tourism, ethnic diversity, and the city: Contemporary geographies of leisure, tourism and mobility (pp. 143-163). London and New York, NY: Routledge.

Faist, T., \& Häußermann, H. (1996). Immigration, social citizenship and housing in Germany. International Journal of Urban and Regional Research, 20(1), 83-98.

Fincher, R., \& Iveson, K. (2008). Planning and diversity in the city: Redistribution, recognition and encounter. New York, NY: Red Globe Press.

Großmann, K., Alexandri, G., Budnik, M., Haase, A., Haid, C., Hedtke, C., . . Shokry, G. (2020). Living with diversity or living with difference? International perspectives on everyday perceptions of the social composition of diverse neighborhoods. In S. Oosterlynck,
G. Verschraegen, \& R. Van Kempen (Eds.), Divercities: Understanding super-diversity in deprived and mixed neighbourhoods (pp. 211-234). Bristol and Chicago, IL: Policy Press.

Großmann, K., Arndt, T., Haase, A., Rink, D., \& Steinführer, A. (2015). The influence of housing oversupply on residential segregation: Exploring the post-socialist city of Leipzig. Urban Geography, 36(4), 550-577. https://doi.org/10.1080/02723638. 2015.1014672

Haase, A., Budnik, M., Großmann, K., Haid, C., Hedtke, C., \& Kullmann, K. (2019). Soziale Differenzierung und zunehmende soziale Heterogenität in Leipzig im Spiegel von Alltagswahrnehmung und Politik [Social differenciation and rising social heterogeneity in Leipzig mirrored in day-to-day perception and policies]. Raumforschung und Raumordnung, 77(5), 525-540. https://doi.org/10.2478/rara-2019-0024

Haase, A., Herfert, G., Kabisch, S., \& Steinführer, A. (2012). Reurbanizing Leipzig (Germany): Context conditions and residential actors (2000-2007). European Planning Studies, 20(7), 1173-1196.

Haase, A., \& Rink, D. (2015). Inner-city transformation between reurbanization and gentrification: Leipzig, Eastern Germany. Geografie, 120(2), 226-250.

Haase, A., \& Schmidt, A. (2019). Grüne Freiräume in Ankunftsquartieren: Funktionen und Herausforderungen für ihre kooperative Entwicklung [Green spaces in arrival neighbourhoods: Functions and challenges with regard to their cooperative development] (UFZ Discussion Paper 4/2019). Leipzig: Helmholtz Centre for Environmental Research.

Hall, S., King, J., \& Finlay, R. (2017). Migrant infrastructure: Transaction economies in Birmingham and Leicester, UK. Urban Studies, 54(6), 1311-1327. https://doi.org/10.1177/0042098016634586

Hans, N., Hanhörster, H., Polívka, J., \& Beißwenger, S. (2019). Die Rolle von Ankunftsräumen für die Integration Zugewanderter: Eine kritische Diskussion des Forschungsstandes [The role of arrival spaces in integrating immigrants: A critical literature review]. Raumforschung und Raumordnung, 77(5), 511-524.

Häußermann, H., \& Siebel, W. (2001). Stadtsoziologie: Eine Einführung [Urban sociology: An introduction]. Frankfurt: Campus.

Hwang, J. (2015). Gentrification in changing cities: Immigration, new diversity, and racial inequality in neighborhood renewal. The ANNALS of the American Academy of Political and Social Science, 660(1), 319-340.

Kabisch, S., Kindler, A., \& Rink, D. (1997). SozialAtlas der Stadt Leipzig [Social atlas of the city of Leipzig]. Leipzig: Helmholtz Centre for Environmental Research.

Kasparek, B., \& Speer, M. (2015). Of hope: Hungary and the long summer of migration. Border Monitoring. Retrieved from bordermonitoring.eu/ungarn/2015/ 09/of-hope-en 
Kullmann, K., Großmann, K., Haase, A., Haid, C., \& Budnik, M. (2018). Lokale Unternehmen im Quartier-Bindungen, Interaktionen, Anpassung an den Quartierswandel [Local enterprises in the neighbourhood: Ties, interactions, adaption to neighbourhood change]. In O. Niermann, M. Drilling, \& O. Schnur (Eds.), Ökonomie im Quartier: Von der sozialräumlichen Intervention zur Postwachstumsgesellschaft [Economy in the neighbourhood: From socio-spatial interventions to a post-growth society] (pp. 93-116). Wiesbaden: Springer.

Kurtenbach, S. (2015). Ankunftsgebiete-Segregation als Potenzial nutzen [Arrival spaces: To use segregation as a potential]. In A. El-Mafaalani, S. Kurtenbach, \& K. P. Strohmeier (Eds.), Auf die Adresse kommt es an: Segregierte Stadtteile als Problem- und Möglichkeitsräume begreifen [It depends on the address: Conceiving segregated districts as spaces of problems and potentials] (pp. 306-328). Weinheim and Basel: Beltz Juventa.

Martin, A. (2018). Leipziger mit Migrationshintergrund 2017 (Teil 2) [Inhabitants with a migrant background in Leipzig]. In Stadt Leipzig (Ed.), Statistischer Quartalsbericht II/2018 [Statistical quarterly report] (pp. 11-15). Leipzig: Stadt Leipzig, Amt für Statistik und Wahlen. Retrieved from https:// static.leipzig.de/fileadmin/mediendatenbank/ leipzig-de/Stadt/02.1_Dez1_Allgemeine_ Verwaltung/12_Statistik_und_Wahlen/Statistik/ Statistischer_Quartalsbericht_Leipzig_2018_2.pdf

Meerow, S., Newell, J. P., \& Stults, M. (2016). Defining urban resilience: A review. Landscape and Urban Planning, 147, 38-49.

Meeus, B., van Heur, B., \& Arnaut, K. (2019). Migration and the infrastructural politics of urban arrival. In B. Meeus, B., K. Arnaut, \& B. van Heur (Eds.), Arrival infrastructures: Migration and urban social mobilities (pp. 1-32). New York, NY: Palgrave.

Murdie, R., \& Teixeira, C. (2011). The impact of gentrification on ethnic neighbourhoods in Toronto: A case study of Little Portugal. Urban Studies, 48(1), 61-83.

Nast, J., \& Blokland, T. (2014). Social mix revisited: Neighbourhood institutions as a setting for boundary work and social capital. Sociology, 48(3), 482-499.

Park, R. E., \& Burgess, E. W. (1925). The growth of the city: An introduction to a research project. In editors (Eds.), The city (pp. 47-62). Chicago, IL: University of Chicago Press.

Pöge-Haus e.V. (2018). Der Hafen der Stadt-Die Eisenbahnstraße zwischen Verheißung und Verruf [Harbour of the city: The Eisenbahnstraße between promises and disreputes]. Pöge-Haus. Retrieved from https://www.pöge-haus.de/de/projekte/hafender-stadt

Portes, A., \& Manning, R. D. (1986). The immigrant enclave: Theory and empirical examples. In S. Olzak \& J. Nagel (Eds.), Competitive ethnic relations (pp. 47-68). New York, NY: Academic Press.
Richter, J. (2000). Städtische Armut in Leipzig [Urban poverty in the city of Leipzig] (UFZ-Bericht 27). Leipzig: Umweltforschungszentrum.

Rink, D., Bernt, M., Großmann, K., \& Haase, A. (2014). Governance des Stadtumbaus in OstdeutschlandGroßwohnsiedlung und Altbaugebiet im Vergleich [Governance of urban regeneration in Eastern Germany: Comparing large housing estate and old building areas]. In F. Roost, B. Schmidt-Lauber, C. Hannemann, F. Othengrafen, \& J. Pohlan (Eds.), Jahrbuch StadtRegion 2013/2014: Schwerpunkt: Urbane Peripherie [Yearbook city region 2013/2014: Focus: Urban periphery] (pp. 132-147). Leverkusen: Verlag Barbara Budrich.

Rodatz, M. (2012). Produktive "Parallelgesellschaften." Migration und Ordnung in der (neoliberalen) "Stadt der Vielfalt" [Productive "parallel societies. " Migration and regulation in the (neoliberal) "City of diversity"]. BEHEMOTH-A Journal on Civilisation, 2(1), 70-103.

Saunders, D. (2010). Arrival city: How the largest migration in history is reshaping our world. London: Windmill Books.

Schillebeeckx, E., Oosterlynck, S., \& de Decker, P. (2019). Migration and the resourceful neighborhood: Exploring localized resources in urban zones of transition. In B. Meeus, K. Arnaut, \& B. van Heur (Eds.), Arrival infrastructures: Migration and urban social mobilities (pp. 131-152). New York, NY: Palgrave. https:// doi.org/10.1007/978-3-319-91167-0

Schmidt, R. (2016). Entwicklung des Ausländeranteils in den Leipziger Ortsteilen von 1992 bis 2015 [Development of the share of foreigners in the districts of Leipzig between 1992 and 2015]. In Stadt Leipzig (Ed.), Statistischer Quartalsbericht [Statistical quarterly report] II/2016 (pp. 38-40). Leipzig: Amt für Statistik und Wahlen. Retrieved from https:// static.leipzig.de/fileadmin/mediendatenbank/ leipzig-de/Stadt/02.1_Dez1_Allgemeine_ Verwaltung/12_Statistik_und_Wahlen/Statistik/ Statistischer_Quartalsbericht_Leipzig_2016_2.pdf

Shaw, S. J., Bagwell, S., \& Karmowska, J. (2004). Ethnoscapes as spectacle: Reimaging multicultural districts as new destinations for leisure and tourism consumption. Urban Studies, 41(10), 1983-2000.

Stadt Leipzig. (1995). Gebäude und Wohnungszählung 1995 Ergebnisse für Leipzig. [Counting of buildings and flats 1995. Results for Leipzig]. Leipzig: Stadt Leipzig.

Stadt Leipzig. (1999). Lebenslagenreport der Stadt Leipzig. Bericht zur Entwicklung sozialer Strukturen und Lebenslagen in Leipzig [Report on life situations in the City of Leipzig. Report on the development of social structures and life situations in Leipzig]. Leipzig: Stadt Leipzig.

Stadt Leipzig, \& Amt für Statistik und Wahlen. (2002). Ortsteilkatalog 2002: Daten zu den Ortsteilen und Stadtbezirken der Stadt Leipzig [District catalogue 
2002: Data on the districts and boroughs of the City of Leipzig]. Leipzig: Stadt Leipzig. Retrieved from https://www.leipzig.de/fileadmin/mediendatenbank/ leipzig-de/Stadt/02.1_Dez1_Allgemeine_Verwaltung/ 12_Statistik_und_Wahlen/Raumbezug/

Ortsteilkatalog_2002.pdf

Stadt Leipzig, \& Amt für Statistik und Wahlen. (2006). Ortsteilkatalog 2006: Strukturdaten der Ortsteile und Stadtbezirke [District catalogue 2006: Data on the districts and boroughs of the City of Leipzig]. Leipzig: Stadt Leipzig. Retrieved from https:// www.leipzig.de/fileadmin/mediendatenbank/ leipzig-de/Stadt/02.1_Dez1_Allgemeine_ Verwaltung/12_Statistik_und_Wahlen/Raumbezug/ Ortsteilkatalog_2006.pdf

Stadt Leipzig, \& Amt für Statistik und Wahlen. (2012). Ortsteilkatalog 2012: Strukturdaten der Ortsteile und Stadtbezirke [District catalogue 2012: Data on the districts and boroughs of the City of Leipzig]. Leipzig: Stadt Leipzig. Retrieved from https:// www.leipzig.de/fileadmin/mediendatenbank/ leipzig-de/Stadt/02.1_Dez1_Allgemeine_ Verwaltung/12_Statistik_und_Wahlen/Raumbezug/ Ortsteilkatalog_2012.pdf

Stadt Leipzig, \& Amt für Statistik und Wahlen. (2018). Ortsteilkatalog 2018: Strukturdaten der Ortsteile und Stadtbezirke [District catalogue 2018: Data on the districts and boroughs of the City of Leipzig]. Leipzig: Stadt Leipzig. Retrieved from https:// www.leipzig.de/fileadmin/mediendatenbank/ leipzig-de/Stadt/02.1_Dez1_Allgemeine_
Verwaltung/12_Statistik_und_Wahlen/Raumbezug/ Ortsteilkatalog/Ortsteilkatalog_2018.pdf

Statistisches Landesamt Sachsen. (2014). Zensus 2011. Gebäude- und Wohnungszählung am 9. Mai 2011 [Census 2011. Counting of buildings and flats on 9. May 2011]. Kamenz: Statistisches Landesamt Sachsen.

Valentine, G. (2013). Living with difference: Proximity and encounter in urban life. Geography, 98(1), 4-9.

van Gent, W., \& Musterd, S. (2016). Class, migrants, and the European city: Spatial impacts of structural changes in early twenty-first century Amsterdam. Journal of Ethnic and Migration Studies, 42(6), 893-912.

Vertovec, S. (2007). Super-diversity and its implications. Ethnic and Racial Studies, 30(6), 1024-1054. https:// doi.org/10.1080/01419870701599465

Werner, F., Haase, A., Renner, N., Rink, D., Rottwinkel, M., \& Schmidt, A. (2018). The local governance of arrival in Leipzig: Housing of asylum-seeking persons as a contested field. Urban Planning, 3(4), 116-128.

Wiest, K., \& Kirndörfer, E. (2019). Paradoxe Aushandlungen von Migration im Diskurs um die Leipziger Eisenbahnstraße [Paradoxical negotiations of migration within the discourse around the Eisenbahnstraße in Leipzig]. Raumforschung und Raumordnung, 77(5), 1-18.

Wilson, K., \& Martin, W. (1982). Ethnic enclaves: A comparison of the Cuban and Black economies in Miami. American Journal of Sociology, 88(1), 135-160.

\section{About the Authors}

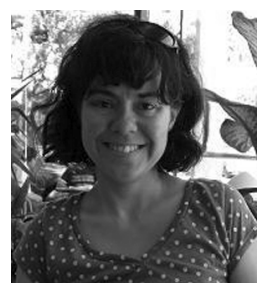

Annegret Haase holds a PhD in Cultural Sciences and works as Urban Sociologist at Helmholtz Centre for Environmental Research in Leipzig, Germany, at the Department of Urban and Environmental Sociology. Her main research foci are sustainable urban development, urban transformations, shrinking and regrowing cities, socio-environmental processes and trade-offs in cities, urban arrival spaces, urban diversity, migration and inequities, environmental gentrification and justice, participation, governance and conflicts, and urban blue-green infrastructure.

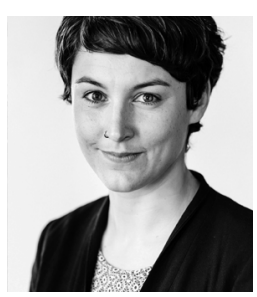

Anika Schmidt has a background in Urban Social Geography and works as a Research Staff at the Department of Urban and Environmental Sociology at Helmholtz Centre for Environmental Research (Leipzig, Germany). She is involved in several transdisciplinary research projects on sustainable urban development and participatory governance. Her research focuses on intersectional approaches towards environmental justice and cooperative arrangements between state and non-state actors in a diversifying society.

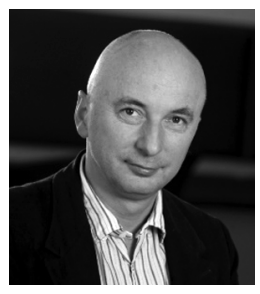

Dieter Rink holds a PhD in Philosophy and works as a Senior Scientist at Helmholtz Centre for Environmental Research in Leipzig, Germany, at the Department of Urban and Environmental Sociology. His research fields are sustainable urban development and urban transformations, urban governance and social movements, urban ecology and urban nature, urban shrinkage and regrowth, and housing and housing policy. 
Sigrun Kabisch is head of the Department of Urban and Environmental Sociology at the Helmholtz Centre for Environmental Research in Leipzig, Germany. Additionally, she is Professor for Urban Geography at the University of Leipzig. She acts as Chair of the Scientific Advisory Board of the Joint Programming Initiative (JPI) Urban Europe. Her main research fields are urban transformations, interdependencies between the social, built, and natural environment, urban demographic change, and urban risks. 